International Journal of Social Science and Economic Research

ISSN: 2455-8834

Volume:06, Issue:01 "January 2021"

\title{
SMART CITY AND THE QUEST FOR INCLUSION: STUDY OF ARDH KUMBH 2019 AT PRAYAGRAJ CITY
}

\author{
Kumari Nidhi (Research Scholar) \\ G.B.Pant Social Science Institute, University of Allahabad \\ DOI: 10.46609/IJSSER.2021.v06i01.016 URL: https://doi.org/10.46609/IJSSER.2021.v06i01.016
}

\begin{abstract}
This paper, therefore, is an effort to understand the practical impact of technocratic urban planning over the peripheral settlements in cities by particularly focusing on the planning of Ardh Kumbh 2019 in Prayagraj city. It is an exploratory study which tries to understand the survival strategy of slum dwellers particularly the Kevat community residing in the Triveni bandh slum which is the nearest slum to the Sangam and mela region. The study explores the opportunities and challenges brought by Ardh kumbh mela 2019 to these slum dwellers in comparison to previous melas. This study adopts an ethnographic approach to meet the objective of the study by conducting in-depth interviews and participant observations. We found in this study that smart planning has an even darker aspect of class dimension. It works on the principle of "creative destruction" under which marginalized and underprivileged are the one who suffer the most.
\end{abstract}

Key-words: Smart City, Urban Inequality, livelihood exclusion, and religious fair

\section{Introduction}

Prayagraj is one of the hundred cities selected under Smart Cities Mission (SCM). Smart Cities Mission is known as the most transformational urban missions. The objective of the mission is to strengthen urban infrastructure through application of smart solutions and provide a better quality of life to citizens. Smart cities develop public spaces such as squares, waterfronts, parks, heritage precincts, traditional markets to make them vibrant urban spaces. In the approach of the Smart cities Mission, the objective is to promote cities that provide core infrastructure and give a decent quality of life to its citizens, a clean and sustainable environment and application of smart solutions. The focus is on sustainable and inclusive development and the idea is to look at compact areas, create a replicated both within and outside the smart city, catalyzing the creation of similar smart cities in various regions and parts of the country. Area-based development will transform existing areas, including slums into better planned ones, thereby improving liveability 


\section{International Journal of Social Science and Economic Research}

ISSN: $2455-8834$

Volume:06, Issue:01 "January 2021"

of the whole city. Application of smart solutions will enable cities to use technology, information and data to improve infrastructure and services. Comprehensive development in this way will improve quality of life, create employment and enhance incomes for all, especially the poor and the disadvantaged, leading to inclusive cities.

This paper, therefore, is an effort to understand the practical impact of technocratic urban planning over the peripheral settlements in cities by particularly focusing on the planning of ardh kumbh 2019 in Prayagraj city. It is an exploratory study which tries to understand the survival strategy of slum dwellers particularly the Kevat community residing in the Triveni bandh slum which is the nearest slum to the Sangam and mela region. The study explores the opportunities and challenges brought by ardh kumbh mela 2019 to these slum dwellers in comparison to previous melas. This study adopts an ethnographic approach to meet the objective of the study by conducting in-depth interviews and participant observations. We found in this study that smart planning has an even darker aspect of class dimension. It works on the principle of "creative destruction" under which marginalized and underprivileged are the one who suffer the most.

\section{Smart city and Inequality: Conceptual debate}

Gilderbloom (2008) in his book titled "Invisible City" raised fundamental questions regarding housing for the elderly, the disabled and the poor. The author brings certain questions into light that why is it that some locales can offer affordable, accessible, and attractive housing, while the large majority of cities fail to do so. Most certainly this book calls for a new housing paradigm that makes the needs of marginalized population visible to policy makers. In addition, Harvey (2008) claims the right to city as a human right. According to him, the freedom to make and remake our cities and ourselves is, one of the most precious yet most neglected of our human rights. Mitra (2013) offers an explanation of limited poverty reduction in a situation of rapid economic growth. Smart cities will be more of everything that a $21^{\text {st }}$ century urban planner, citizen and elected official want: more efficient, more sustainable, and more inclusive. Kondepudi (2015) provides an insight into what is meant by a Smart City and the underlying factors that make a city smart. The authors answer the question of "what constitutes a smart city" by presenting a multi-faceted approach including a detailed analysis of classical smart city definitions, attributes of a smart city, industry viewpoints and efforts by standards developing organizations. Ultimately, the authors propose a holistic definition of a smart city where "smart city means different things to different stakeholders, and therefore has a strong dependence on the"lens" through which a smart city is viewed. Roy (2016) argues that the smart city initiative, in its urge to replicate the developed economy model, became a carrier of neo-liberal urbanism, overlooking the range of diversity in Indian cities. The following issues are challenging the sustainability and inclusiveness of the initiative. Clark (2020) seems doubtful about the presumed notion behind Smart Cities Mission. In her book titled Uneven Innovation, Jennifer 


\section{International Journal of Social Science and Economic Research}

ISSN: $2455-8834$

Volume:06, Issue:01 "January 2021"

Clark considers the potential of these emerging technologies as well as their capacity to exacerbate existing inequalities and even produce new ones. She reframes the smart city concept within the trajectory of uneven development of cities and regions, as well as the long history of technocratic solutions to urban policy challenges. Clark argues that urban change driven by the technology sector is following the patterns that have previously led to imbalanced access, opportunities and outcomes. The tech sector needs the city, yet it exploits and maintains unequal arrangements, embedding labour flexibility and precarity in the built environment. Technology development, Uneven Innovation contends, is the easy part; understanding the city and its governance, regulation, access, participation, and representation - all of which are complex highly localized - is the real challenge. Clark's critique leads to policy participations that present a path toward an alternative future in which smart cities result in more equitable communities.

\section{Historical background of Prayagraj city}

The lack of housing and basic services at the required pace to meet the challenges of urbanization has resulted in the development of slums and squatter settlements with wider ramifications on the health, safety and well-being of the citizens. In 2001, there were 23.5 percent of households in urban areas which were living in slums. In 2011, it has come down to 17.4 percent. But there are still 13.74 million slum households and 68 million people living in the slum areas (Census, 2011). In context of Uttar Pradesh, though the state is considered as one of the less urbanized states of India, it has second largest urban population in the country. About $22 \%$ of the population lives in urban areas in Uttar Pradesh, which constitute more than 44 million. As per the statistics of committee on Slum Statistics/census, 2011, Government of India, about 10.8 million urban population of Uttar Pradesh is living in slums, which constitute about $24 \%$ in urban population. In spite of various central and state government programmes implemented in the state the problem of urban poverty and slums is still prevailing on large scale. The state of Uttar Pradesh is one of the prominent states in the North eastern region of India with Lucknow as its capital, falling under „, $\mathrm{A}^{\text {ce }}$ categoryl with Allahabad classified as „B category city. Allahabad Municipal Corporation, is one of the old municipalities of the state and it came into existence in the year 1864.

\section{Mythological importance of Prayagraj city}

The city was known earlier as Prayaga which existed from Vedic period. Excavation in the town states that city is originated before 700 B.C. Many ancient kingdoms conquered prayaga and made it as their capital, the important kingdoms are Maurayans, Guptas and Kushans, etc. Later, the Mughals took over and Prayag rose to prominence. Akbar built a magnificent fort (viz. Allahabad fort), on the banks of the holy sangam and named the town as Illahabad in 1575. Later in 1805 the city was ceded to British by Nawab of Awadh after losing battle of Bauxar. 


\section{International Journal of Social Science and Economic Research}

ISSN: $2455-8834$

Volume:06, Issue:01 "January 2021"

Allahabad was active during Indian Mutiny, 1857. After mutiny was quelled, the British established the High Court, the Police Headquarters and the Public Service Commission in the city. This transformed Allahabad into an administrative center and served as capital of United Province from 1877 to 1920. After the independence, in 1949 Uttar Pradesh state was formulated Lucknow as its capital. Prayagraj is the most important pilgrim,age centre for Hindus because of the significance of the confluence of the holy river Ganga, Yamuna, and the mythical Saraswati river. According to legends, Vishnu was carrying a Kumbh (pot) of amrit (nectar), when a scuffle broke out and four drops were spilled. They fell to earth at the four tirthas of Prayag, Haridwar, Nashik and Ujjain. A tirtha is a place where the devout can attain salvation. The event is commemorated every three years by the Kumbh mela, held at each tirtha in turn; the Sangam is known as Tirtharaj, the "king of tirthas and here the kumbh is held once in every twelve years, which is the greatest and holiest of all; while ardha kumbh is held once in every six years. The Kumbh mela is the largest congregation in India, attended by millions. The mela is especially known for the presence of an extraordinary array of religious ascetics - sadhus and mahants enticed from remote hideways in forests, mountains and caves. The sadhus, who see themselves as guardians of the faith, approach the confluence at the scheduled time with all the pomp and bravado of a charging army. The most recent kumbh mela was held in 2013 and ardha kumbh in 2019.

\section{Physical Characteristics of the City}

\section{Location}

Prayagraj is a Class I town, municipality and administrative headquarters of Allahabad District, falls under Prayagraj division of Uttar Pradesh. Prayagraj city spatial extension falls at $25^{\circ} 28^{\text {ce }} \mathrm{N}$ latitude and $81^{\circ} 54^{\mathrm{ee}} \mathrm{E}$ longitude. It is bounded by Pratapgarh in the north, Bhadohi in the east, Rewa in the south and Kaushambi in the west. The city of Prayagraj is situated at the convergence of two sacred rivers, the Yamuna and the Ganges. The confluence is known as Sangam. It is at an elevation of 98 meters above mean sea level. Prayagraj lies on the western part of the Great Indo-Gangetic Plain region and is under laid with sediments deposited in successive stages. There can be three distinct physical parts of the city, quite like the district itself - (i) Trans-Ganga or the Gangapar Plain, (ii) the GangaYamuna doab (confluence), and (iii) Trans-Yamuna or the Yamunapar tract, all three of which are formed by Ganga and its tributary Yamuna. The Municipal Corporation of Prayagraj administers an area of $82 \mathrm{sq} \mathrm{km} \mathrm{with}$ a population of 11, 17,094 (Census, 2011) among which male and female are 601,363 and 515,731 respectively. Total children (0-6 years) in Prayagraj city are 102,556 were 54,660 are boys and 47,896 are girls. The child forms $9.12 \%$ of total population of Prayagraj City. The town has witnessed a constant increase in population from 1951 to 2011 with a varying decadal growth rate. The population increased by four folds over the last six decades with increase in 


\section{International Journal of Social Science and Economic Research}

ISSN: $2455-8834$

Volume:06, Issue:01 "January 2021"

population from 332,295 in 1931 to $11,17,095$ in year 2011. Prayagraj city comes under Prayagraj metropolitan area along with Cantonment board and urban outgrowths.

Slum Population: As per 2001 census, slum populations in the city are 126,646 residing in 18,558 households constituting $13 \%$ to the city population, but as per the Oxfam trust survey in 2005 , there are 283 poor settlements with a population of $3,63,550$ (30\% of the city population).

The average slum household size is 6.8 which is slightly greater than city household size of 6.4. A preliminary annexure I verification survey has been carried out in June, 2011 on the basis of NBO annexure format (RAY guidelines). As per the survey, slum population in the city are 4,70,467 and households are 91,025 residing in 185 slums of city. The household size of slums came down to 5.4 from 6.8 in 2001.

\section{Socio-economic background of slums}

D'Souza (1979) claims that the poor and the slum-dwellers occupy the lowest rung of the social hierarchy and their low status is socially inherited and perpetuated. Further he rejects the view of "culture of poverty" and presumes that the disadvantaged condition of slum dwellers is forced upon them by the dominant section of the community to subserve their own interests. It implies that the dominant section of the community exerts its power, although in devious ways, in forcing some people to remain perpetually in servitude. In addition, Davis (2006) wrote 1980 'scrisis established informal survivalism as the new primary mode of livelihood in a majority of third world cities. The informal sector is most certainly known as a living museum of human exploitation. The living conditions in slums represent the worst of urban poverty. Individuals and communities living in slums face serious challenges in their efforts to survive. Every slum is different in its origin, location, size and demographic characteristics. All characteristics are not common for all slums in the city. It may differ due to various reasons such as its appearance, economic condition, overcrowding of buildings, tenements, population, health and sanitary conditions, morality, way of life, standard of living, isolation of other residential communities etc. Prayagraj City has a total of 185 slums, all the slums are non-notified with $83 \%$ of these built on lands under private ownership. Over $25 \%$ of the slums have been into existence for more than 75 years in the city. The total population of the slums is $4,70,467$ which is about $42 \%$ of the total city population. With respective physical location, $8 \%$ of slums are found along the major road network; $11 \%$ along railway lines and $62 \%$ along nallahs and water bodies, thereby vulnerable to natural disasters/flooding. Slum settlements are almost equally distributed in core and fringe areas.

Table 1 Comparison of City population and area against the Slums

\begin{tabular}{|l|l|lll|ll|ll|lll|}
\hline City & Slum & $\%$ & of & Slum & City & Area & Total & Area & $\%$ & of & slum \\
\hline
\end{tabular}


International Journal of Social Science and Economic Research

ISSN: 2455-8834

Volume:06, Issue:01 "January 2021"

\begin{tabular}{|l|l|l|l|l|l|}
\hline Population & Population & $\begin{array}{l}\text { population to } \\
\text { city } \\
\text { population }\end{array}$ & $\begin{array}{l}\text { under slums } \\
\text { (Ha) }\end{array}$ & $\begin{array}{l}\text { area to city } \\
\text { area }\end{array}$ \\
\hline $11,17,094$ & 470467 & $42 \%$ & 8200.00 & 450.42 & $5 \%$ \\
\hline
\end{tabular}

Source: Census 2011, RAY Primary Survey, 2011

\section{Significance of Triveni Bandh (Daraganj) slum for this study}

This slum plays major role in the religious functioning of this city i.e. Prayagraj. This is the nearest slum to the Sangam where Kumbh mela is organized. Keveat is a community which resides in this slum in a good number. Kevat is also referred to as Mallah, the boat man who lives along the banks of major rivers of Uttar Pradesh. Kevat is derived from Sanskrit-Kaivarta, which refers to the people who depend on the riverine or aquatic ecology for subsistence. Similarly the term Mallah refers to boatmen or boatmakers, ferry-service persons, who also simultaneously earn livelihood through fishing in the river stream. Regarding social division of Kevat/Mallah, it was informed that they are broadly divided in eight groups, viz, Chai, Tiyar, Banthawa or Bhatao, Gudiya, Bind, Dhiya or Dhivar, Polahar and Natoniya.The hierarchical rank of all the sub-castes is treated equally and collectively belongs to Sudra of Hindu classificatory varna system. It was reported that the primary occupation of kevat/Mallah primarily revolves around major river streams of the state since ancient times. Those bygone age river streams were truly navigable and were lifeline in the transportation of essential commodities as well as an effective mode of communication for far places. Kevat/Mallah have expertise in navigation making and repairing of water-crafts of various sizes as well as guarding the boats on route. Apart from this they were skilled in fishing, processing fish, making nets and grills, shifting transport operation from inland water to surface, Kevat/Mallah became more localized group and land-mass became important in continuing their subsistence pattern gradually. Fishing and transporting people on their boats are the primary traditional occupation. Agriculture and laboring in farms is a secondary occupation.

\section{Socio-economic condition of slum dwellers of Triveni bandh slum}

Though slum population is a mixed population of diverse caste and creed group, this Triveni bandh slum is not exceptional in that case. Despite this Kevat (Bind subcaste) is in majority. They have settled in that slum long back as most of the youths shared that they are the third generation who are residing here. The main occupation of the people residing here is associated with cremation of dead bodies according to Hindu religion. Lakhan Bind (pseudo name) shared that this is ninty year old family occupation and family is engaged in it since three generations. 


\section{International Journal of Social Science and Economic Research}

ISSN: $2455-8834$

Volume:06, Issue:01 "January 2021"

Including his grandfather there are eight persons who got registration as a contractor for cremation from district administration and in April every year they have to renew it by paying Rs eight hundred annually. This cremation includes variety of activities so it provides livelihood opportunities to people residing in this locality. For instance cremation activity needs Mahapatra (who burns the dead body), Panda (who perform religious procedures), Dom (who set fire to the dead body), Nau (barber), cart person (who brought woods near the ghats). Income of all these depends on the customers will; as some of them willingly pay high amount while there are customers who pay minimal charges. These contractors are mainly supplier of woods which is required for burning the dead body. A fifty-eight year old Gopal Shukla also runs a shop of firewood who is not a registered contractor for shamshan ghat. But whenever these contractors need firewood urgently they buy from him. Gopal Shukla said that customers who came for cremation may buy (five man/seven man/nine man) depending upon their capacity and will. There is an electric crematorium too in this locality and it charges only five hundred per body. Then there is a obvious question which comes that if there is crematorium then why people came to shamshan ghats. In response to that question one Panda (Brahmin) said that "those who have great faith in divinity they must follow the whole Hindu ritual of cremation at ghats rather than doing at electric crematorium" (jinlogo ki apne parijanon ke prati sachhi astha hai unko lash ghat pe jalaye bina santusti nahi milegi, ghat par insan apne aankho se lash ko mitti hote dekhta hai; wahi lashghar me to sab 5 mint ka khel rahta hai aur itni lashe number me hoti hai, kisi ki mitti uthakar kisi ko de dete hai). Chhotu Bind (49 year old) said that electric crematorium is not working nowadays. As a result unclaimed corpse and poor people suffered a lot. Sometimes police came with unclaimed corpse then we try to arrange the cremation with unburnt/residual firewood. They shared that this ghat is named as Daraganj shamshan ghat while there is another shamshan ghat in Rasoolabad where there are sixteen registered contractors do the same work. They shared that Rasoolabad ghat is far better in terms of basic amenities such as pucca ghat, toilet, water taps etc. Unfortunately, Daraganj ghat lacks all these. There are sixteen persons of this slum work under Namami Gange project where they are assigned to make ghats at the river bank. One person among them said the nature of work they do is "ghat banana aur patna". Two persons run petty shop for tea and paan. Ajit kumar Bind (Pseudo name) who runs a shop said that in this sector everyone's occupation is associated with each other, so we are well connected to each other and we live like a family and also we support each other in any sort of crisis.

Females of this locality do farming in Ganga doab and cultivate vegetables primarily which requires lots of hard work as irrigation is very difficult in sunny days or do household work. One afternoon around $3 \mathrm{pm}$ one fifty year old lady named Sita bind (pseudo name) sitting at the road side along with five other women of mixed age group said that "they do not have any work to do and they have to spend their day time unproductively" (abhi koi kaam nahi hai humlogo ko baithe baithe din bit jata hai). When the question posed to the women sitting over there that 


\section{International Journal of Social Science and Economic Research}

ISSN: $2455-8834$

Volume:06, Issue:01 "January 2021"

don't they do farming, they answered that it is very difficult especially in summer season. On the other hand it is risky too because there is a risk of flood which can destroy the vegetation. They said that we only do some work during Magh mela period. Every woman gets engaged in some economic activity through street vending during mela period. Magh mela is an annual event for the residents of Prayagraj and of course religious disciples from all over the country. Some of them also do vending work during Sawan mela. During Savan which is a month event in which disciples collect water from Sangam and walking through the G.T. road they put water over Baba Vishwanath temple in Varanasi. In this season people of this slum put stalls for kanwar, flower, gerua dress and other essential puja items and sell it.

\section{Opportunities and challenges brought by Mela (Ardh-Kumbh, 2019)}

The Ardha Kumbh mela 2019 was held at Prayagraj from January $15^{\text {th }}, 2019$ to March $4^{\text {th }}, 2019$. There were six shahi snans (holy bath) on the occasion of Makar Sankranti, Paush purnima, Mauni amawasya, Basant Panchami, Maghi Purnima and Mahashivratri. According to government estimates, 2019 mela has witnessed largest human gathering on earth of 120 million devotees. Kumbh nagri, almost 100 times the size of the Vatican city, is like a country in itself. The over month-long fair is marked by the construction of a massive tented township, complete with cottages, huts, platforms, civic facilities, administrative and security measures. It is organized immaculately by the government, the local authorities (Prayagraj Mela Authority) and the police. It has its own hospitals, police force, fire brigade, water, food, sanitation, roads and pontoon bridges. Traders bring local indigenous art and akharas that host sermons through day and night. And all of this is set up in just 4 months. Hence, with the perspective of organizing fair every year and Kumbh of course, Prayagraj city becomes more significant for the study of urban planning and inclusiveness. The Ardh Kumbh 2019 was organized in most technocratic form envisaged to achieve competitiveness in order to attract investment and operational efficiency in service delivery through smart solutions such as portable toilets, changing rooms at ghats, tented townships, drinking water facility, massive security arrangements etc. On the other hand, there is no drinking water and sanitation and also no housing facility for slum dwellers residing in Triveni bandh slum. Every year in Monsoon season the whole slum is getting devastated by the flood. So the slum-dwellers see mela as an economic opportunity for their survival which is organized after monsoon. Although the cremation at Daraganj ghat would be banned during mela period, they would have another opportunity to earn through vending activities. They wait for the mela over the year and immediately after monsoon they do preparations for mela by making kande (cooking fuel made by cow dung) and earthen stove which is generally used by kalp-vasi (disciples) and sadhus who stay there throughout the mela period. They do different kind of vending work for everyday accessories starting from vegetable, spices and other grocery items to other items like toys and cosmetics. But Ardh Kumbh Mela of 


\section{International Journal of Social Science and Economic Research}

ISSN: $2455-8834$

Volume:06, Issue:01 "January 2021"

2019 was not proved beneficial for Triveni bandh slum dwellers just because of its technocratic form. They said massive deployment of armed forces did not allow them to do vending work due to security concern. Even if they tried police personnel throw their selling items. On the days of shahi snan, they were not even allowed to come out of their homes which were the days of greater incomes in previous melas. Therefore, the smart planning of mela through technocratic approach was not inclusive for the slum-dwellers and it further pushed them to the margins.

\section{Conclusion}

Slums represent a major policy challenge for developing economies in the $21^{\text {st }}$ century. The conceptualization of slums as places of poverty traps and the concept of "smart city" itself is contradictory in nature which assumes that the prevalence of slums and urban poverty should decrease as markets develop and the forces of economic development come under way, specially for the city known for its heritage value. In addition to belong trapped in low-human capital and low-investment equilibriums, slum areas are generally places of extreme policy neglect, well beyond the lack of public goods provisions. An inclusionary and livelihood approach can counter the existing exclusionary tendencies related to infrastructure, access, mobility, etc. The focus of the livelihood approach is on strengthening the income earning capacity of poor people in order to improve their well-being. The livelihood framework provides an analytical starting point for understanding urban poverty and deprivation, by identifying the main factors which affect livelihoods and the relationships between them. In this regard, Cabannes (2018) has rightly emphasized on the role of citizens as active agents of urban change rather than as passive victims of global capitalism.

\section{References}

Cabannes, Y. Mike Douglass and Rita Padawangi (2018) "Cities by and for the People" in Cities in Asia by and for the People, Amsterdam, Amsterdam University Press.

Clark, J. (2020) Uneven Innovation: The Work of Smart Cities, New York, Columbia University Press.

Davis, M. (2006) Planet of Slums, London, Verso.

D’souza, V.S. (1979) "Socio-Cultural Marginality: A Theory of Urban Slums and Poverty in India”, Sociological Bulletin, 28(2):9-24.

Gilderbloom, J.J. (2008) Invisible City: Poverty, Housing and New Urbanism, Texas, University of Texas Press.

Harvey, D. (2009) Social Justice and the City Athens, University of Georgia Press. 
International Journal of Social Science and Economic Research

ISSN: 2455-8834

Volume:06, Issue:01 "January 2021"

Marx, B., Thomas Stoker and Tavneet Suri (2013) "The Economics of Slums in the Developing World" The Journal of Economic Perspectives, 27(4): 187-210.

Mehrotra, S. (2013) "Behind the Exotica: Maha Kumbh 2013" Economic and Political Weekly, 48(9): 64-68.

Mitra, A. (1990) "Duality, EmploymentStructure and Poverty Incidence: The Slum Perspective", Indian Economic Review, 25(1): 57-73.

Mitra, Arup. (2013) Insights into Inclusive Growth, Employment and Well-being in India, New Delhi, Springer.

Rakodi, C. and Tony Lloyd-Jones (2002) Urban Livelihoods: A People-centred Approach to Reducing Poverty, London, Earthscan.

Roy, S. (2016) "The Smart City Paradigm in India: Issues and Challenges of Sustainability and Inclusiveness", Social Scientist, 44(5): 29-48.

Sharma, R.N. and K.Sita (2000) "Cities, Slums and Government", Economic and Political Weekly, 35(42): 3733-35.

Smart, A. (2008) “Class and State in Urban Settings”, Anthropologica, 50(2):207-210.

MoUD (Ministry of Urban Development), "Slum Free City Plan of Action - Allahabad" Regional Centre for Urban and Environmental Studies. 